\title{
THE AHMADIYA MOVEMENT *
}

Mr. Walter's book on the Ahmadiya movement is one of the series "The Religious Life of India," the purpose of which is "to produce really reliable information for the use of all who are seeking the welfare of India." Some readers may be disappointed that the tenets and false claims of the Ahmadiya Movement are so calmly stated, they would have preferred to see the author break forth in indignation at the many unfair misrepresentations which Ghulām Ahmad and his followers make concerning Christian doctrine and practice, or at the frequent and deliberately blasphemous statements that their writings contain. But the calm and patient statement of fact is one of its greatest assets of the study. The reader feels that here we have no one-sided presentation by a propagandist but a fair, accurate and painstaking review of the rise and development of this strange movement among Indian Moslems.

Before saying anything further of the book itself, it is fitting that one express a sense of the deep loss which Christian work in India has sustained on the death of the author who succumbed to the after affects of influenza last year. From one who could give us such a valuable book as "The Ahmadiya Movement," great things, indeed, might have been expected.

The book is divided into seven chapters:

1. Mirza Ghulām Ahmad (Biographical).

2. The Distinctive Claims of Ahmad.

3. The Ahmadiya Movement and Orthodox Islam.

4. The Ahmadiya Movement and Christianity.

5. The Ahmadiya Movement and the Indigenous Religions of India.

6. The Ahmadiya Community.

7. The Significance of the Ahmadiya Movement.

There are added an Ahmadiya Bibliography and seven Appendixes.

The Ahmadiya Movement was, in its beginning, an attempt to bring life into "the dead Mohammedanism" of the mass of Indian Moslems. Mirza Ghulām Ahmad clearly saw that even in India Christianity was living,

- The Ahmadiya Movement. By H. A. Walter M. A. The Religious Life of India Series. Association Press, Calcutte (Oxford Univeraity Press) 1918. Dp. 185. Price $\$ 1.00$. 
while orthodox Islam was dead. His early intercourse with Christian missionaries brought home to him that the cause of this was that Christians believed in an ascended and living Christ, while Moslems looked for guidance to a dead and buried prophet. With true Moslem incapacity to understand spiritual truth he rejected the essential teachings of Christianity as unreasonable, and clung to the faith of his fathers, but felt the need of reformation and awaking.

Like Mohammad himself, Mirza Ghulām Ahmad was a "pathological case." From his youth he had strange visions and dreams, which he interpreted himself and in which he always figured in some pre-eminent capacity." (p. I5.) After his father's death, "His hatred of the world grew upon him and various eccentricities developed." (p.' 14) A careful study of the earlier years of Ghulam Ahmad's life might throw considerable light on the workings of Mohammed's mind and lead us to understand more clearly the experiences by which he finally arrived at the conclusion that he was a chosen prophet of Allah.

Gradually, Ghulām Ahmad began to believe, or, at least, claimed to believe that these visions and dreams were "revelations" from Allah. In 1891 he "announced that he was both the promised Messiah and the Mehdi expected by the Moslems." (p. 16) It was here that he practically broke with orthodox Islam, for though he did not profess to bring a new book, he claimed to be a prophet, while orthodox Islam recognizes no prophet after Mohammed. Further, his conception of the expected Mahdi was contrary to the accepted teachings of orthodox Islam, which maintains universally that the Mehdi "will be a man of blood who will lead forth the entire host of Islam in a world-wide and altogether victorious jihad." (p. 71) Ghulam Ahmad's teachings on jihād appeared to contradict such a conception, though as Dr. Griswold (quoted p. 72) points out Ghulman Ahmad was apparently opportunist in his teachings on this point for he appears to have held that in altered circumstances (i. e. should British control weaken) jihad would be a 
duty, seeing that he declared one of his "five principal doctrines" to be "To preach Islamic truths with reasoning and heavenly signs and to regard ghaza or jihäd as prohibited under present circumstances." (p. 72) (The italics are Dr. Griswold's.)

In claiming to be a prophet, the second Messiah and the long-expected Mehdi in one, Ghulàm Ahmad pressed far beyond his original purpose of reforming and reviving Islam, and the Ahmadiya Movement is in reality the rise of a new sect in Islam-a sect which, in many respects, is marked by a special bitterness and antagonism towards Christian doctrine, especially the belief in the death, resurrection, and ascension of our Lord.

While being, in special, antagonistic to Christianity, the Ahmadiya Movement is also in strong opposition to orthodox Islam, and the Ahmadis do not hesitate to regard orthodox Moslems as unbelievers (kāfirs), because they will not acknowledge Ghulām Ahmad as a prophet. The orthodox party, on their side, equally regard the Ahmadis as heretics, if not unbelievers, and the opposition between the two parties is strong and bitter. Only the powerful arm of the British Government prevents the employment of physical and violent methods of "argument" on both sides.

While the British authorities recognize the Ahmadis as Moslems, and protect them, the late Amir in Afghanistan, on the 14th of July, 1903, put to death two of Ghulām Ahmad's followers who sought to carry their teachings into Afghanistan, a purely Mohammedan country. These two Ahamdis were stoned to death as renegades from Islam. (p. 70)

The Ahmadiya Movement is wholly unlike the wellknow movement inaugurated by the late Sir Syed Ahmad Khan and whose best known living exponent is Syed Amir 'Ali : which was merely an attempt to reform Islam on rationalistic basis, and to assimilate the results of Western scholarship. Indeed, in some ways, the Ahmadiya Movement is a protest against the modern Mu 'tazalite teaching.

Mirza Ghulām Ahmad and his followers, while pro 
fessing to accept the results of Western scholarship, do so only in so far as it suits their purpose. They scour the literature of the world for any statements, which seem to them to throw doubt on the truths of Christianity, or to weaken its claims to recognition as a divine revelation, and yet they retain, throughout, a blind belief in the wildest stories of Moslem tradition concerning the miracles of Mohammed, and add to these equally wild statements concerning the prophetic powers of their "Second Messiah."

The Ahmadiya Movement is bitterly opposed to all the essential teachings of Christianity. It denies the Fall, the Trinity, the Incarnation, the Atonement, the Living Presence of the Holy Spirit. In opposition to orthodox Islam it also denies the Virgin Birth of our Lord as well as $\mathrm{His}$ sinlessness.

We have already pointed out that Mirza Ghulām Ahmad denies not merly the death on the cross, but he goes further and claims that he has "proved" that Jesus Christ did not ascend to heaven, but lived on earth after the crucifixion, having been stolen from the tomb and revived by his followers, after which he wandered to Kashmir, when he died at the age of 20 and was buried at Srinagar. The main "proof" of this is the fantastic story of the miraculous "discovery" by Ghulām Ahmad of the tomb itself.

Yet Ghulām Ahmad, like his predecessor Mohammed, was plainly an opportunist. For, while, whenever it appears to him advantageous to do so, he vilifies the character of Jesus, he yet claims on many occasions to admire His character and teachings, and, indeed, professes to have come in the spirit and power of the Christ so that in him is fulfilled the great hope of all Christendom. He agrees with most Christian teachings whenever this appears to be likely to further his cause; but, whenever it appears opportune to do so, he denies the same teachings and pours upon them the vials of his contumely.

One of the strongest impressions received from the reading of this book is a feeling of amazement at the unrestricted freedom with which the leaders and agents of 
the Ahmadiya Movement have been permitted to write and publish in India articles and pamphlets which cannot but shock-and in some instances were apparently intended to offend-Christian feelings. To show to what lengths they have been permitted to go, let us quote but one statement:

"The manner is very amusing in which the three Persons of Trinity (sic) shifted the responsibility of the reformation of mankind from one to the other. There was the Father, who, having a certain superiority, in name if not in reality, thought of restoring man to his original state-one should (sic) think it means the savage state, for human progress has been gradual from a lower to a higher stage-but he found his hands tied by the strong manacles of justice. Out of final reverence the Son offered himself, but when he came into the world, he went away with the empty consolation that the third partner shall come and teach them all truths and guide them into all truth. The third Person, being only a pigeon, (the italics are ours) found himself unable to undertake the teachings of truths, but thought he had done his duty by teaching the apostles a few dialects, which they were thus able to speak stammeringly" (p. 95).

Well does Mr. Walter write, "Could deliberate blasphemy go to greater lengths?"

Yet against a liberty of the press which permits the publication of such perverse and unworthy distortions of the truth we do not object, if Christian apologists and controversialists are given a free hand in publishing what. ever they may deem fitting and helpful in carrying on their missionary enterprise. We may be certain that however bitter their words may appear to Moslems or others, they will never be studiously blasphemous.

The scales of censorial justice are not always held even, and to an outsider such action on the part of British authorities gives the impression that these authorities of ten toady to Moslem sentiment to such a degree that instead of giving to Moslems the idea of justice and impartiality, they encourage the belief that the British Government, for some reason, is afraid of Islamic sentiment.

Since the death of Mirza Ghulām Ahmad, which took place in 1908, there has been a secession among his fol. lowers. The Qādiān Party, following the second Khalifa, Mirza Bashir ud-Din Mehmoud Ahmad, the son of the Founder, has continued and probably will indefinitely continue to be in opposition to the orthodox Moslems: 
for they claim that Mirza Ghulām Ahmad is one of the prophets and that "only those are true Moslems who believe in the prophets of God, those who do not so accept Mirza Ghulām Ahmad are 'kafirs' (unbelievers)."

Mr. Walter thinks that this party may continue and grow and perhaps finally become a recognized sect in Islam. This may be so: but we think that the future continuance of this party will depend largely, it not wholly, on the protection afforded it by the impartial Christian Government of India. There can be little doubt, we think, that if Mirza Ghulam Ahmad had attempted his propaganda in any independent Moslem country he would have succumbed to such fate as befell his two followers in Afghanistan. Orthodox Islam has no recognition to give to any one who comes as a new prophet, and the ideal Mahdi of Islam must ever remain, as we have already pointed out, a victorious warrior.

The other party, that of Lahore, of which Maulvr Muhammad 'Ali is the most prominent leader and best known representative, has approached orthodox Islam, and, in the view of $\mathrm{Mr}$. Walter, will probably be ultimately merged in Islam. "In their writings and missionary work the person and claims of Mirza Ghulām Ahmad are almost invisible. At most they consider him to be only the latest of the Mujaddids (Reformers) and his influence survives only in their beliefs in the death of Jesus and his burial in Kashmir and in the hostile attitude toward other religions which is found among them to an extent that does not exist among educated Moslems generally in India today." (p. I16).

In conclusion we strongly recommend "The Ahmadiya Movement" to all who desire to know what this Movement is and how it arose. It is to be specially hoped that the book will have a wide circulation among all who are interested in Christian missions to Moslems.

W. R. W. GARDNER.

Edinburgh, Scotland. 